\title{
Kirjallisuuden ikuinen ja ajankohtainen ylirajaisuus
}

\section{Hanna-Leena Nissilä, "Sanassa maahanmuuttaja on vähän kitkerä jälkimaku." Kirjal- lisen elämän ylirajaistuminen 2000-Iuvun alun Suomessa. Oulu: Oulun yliopisto, Acta Universitatis Ouluensis B Humaniora 136. Oulu, Oulun yliopisto 2016, 116 s..}

Hanna-Leena Nissilä on tehnyt uranuurtavaa suomalaisen kirjallisuuden ylirajaistumista koskevaa tutkimustyötä jo pitkään. Hänen väitöskirjansa on tämän työn mainio summa. Kuten Nissilä sivulla 41 toteaa, "uuden ylirajaisen kirjallisuuden ilmiötä ja kirjallisen elämän ylirajaistumista kartoittavaa tutkimusta ei ole meillä [eli Suomessa] aiemmin tehty”. Artikkeliväitöskirjassa vuosina 2007-2016 ilmestyneiden artikkelien avulla voi kartoittaa, miten kirjallisuudentutkimuksen "maahanmuuttajakirjallisuutta" ja ylirajaisuutta koskeva keskustelu kehittyi viime vuosikymmenen aikana. Nissilä mainitsee halunneensa julkaista ajankohtaisesta aiheesta osatutkimuksia työnsä eri vaiheissa ja näin kartuttaa yhteistä tietoa uudesta ylirajaisesta kirjallisuudesta 2000-luvun alun Suomessa. Tässä on onnistuttu, sillä Nissilä on artikkeleillaan osallistunut kehitykseen, jota hän väitöskirjassaan, varsinkin sen johdanto- ja loppuluvussa taitavasti tarkastelee.

Väitöskirja sisältää viisi vertaisarvioiduissa lehdissä ja monografioissa ilmestyneitä tai ilmestyviä hienon kokonaisuuden muodostavaa artikkelia: "Jälkikoloniaalinen naiskirjoitus - suomalaisen kirjallisuuden uudet tulokkaat" (2007), "Ranya ElRamly ja Auringon aseman vastaanotto" (2009), "Women writers with im/migrant backgrounds transnationalizing Finnish literature Perspectives on the reception of debut novels by Lindén, ElRamly, Abu-Hanna and Salmela" (2018), yhdessä Eila Rantosen kanssa kirjoitettu "Kansainvälistyvä kirjailijakunta" (2013), ja "Vuotoja kansallisessa säiliössä - muistiinpanoja tutkimusmatkaltani ylirajaiseen kirjallisuudentutkimukseen" (2016). Niitä kehystävät pitkä johdantoluku, "Ylirajaisuus kirjallisuudentutkimuksen lähestymistapana" -niminen luku, sekä "Johtopäätökset"-loppuluku. Johdannossa esitellään tutkimuksen taustaa sekä artikkeleille yhteisiä, tutkimuksen keskiössä olevia tutkimuskysymyksiä. Etusijalle nousee kysymys, "miten globalisaatio, kansainväliset muuttoliikkeet ja muuttunut kulttuuris-yhteiskunnallinen tilanne ovat näkyneet kirjallisessa elämässä 2000-luvun alun Suomessa" (s. 42). Aineistona ovat pääasiallisesti muutamat kaunokirjalliset tekstit, Ranya 
ElRamlyn, Umayya Abu-Hannan, Zinaida Lindénin ja Alexandra Salmelan esikoisteokset sekä niiden vastaanotto eri medioissa. Nissilä on tehnyt perusteellisen työn kartoittamalla "ylirajaisen kirjallisuuden" kenttää, keräämällä tietoa kirjailijoista, heidän taustoistaan, teksteistään ja mahdollisesta yhteiskunnallisesta vaikuttamisestaan. Hän on tuonut esiin kentän moninaisuutta varsinkin johdantoluvussa sekä Suomen nykykirjallisuus -julkaisuun kuuluvissa Eila Rantosen kanssa kirjoitetuissa artikkeleissa, joista toinen sisältyy väitöskirjaan.

Hanna-Leena Nissilä hahmottaa neljä tutkimuksellista tasoa, joilla kirjallisen elämän ylirajaistumisen tarkastelu tutkimuksessa tapahtuu: ylirajaisen representaation taso, instituution taso, kirjallisuushistoriallinen taso ja metodologinen taso. Ne kietoutuvat yhteen kaikissa väitöskirjan osioissa. Artikkelit sisältävät kulttuurintutkimuksellisesti orientoituneita kontestualisoivia tulkintoja, jotka hyödyntävät muun muassa feministisiä, jälkikoloniaalisia ja intersektionaalisia teorioita sekä nationalismin, toiseuden ja erilaisuuden analyyseja. Instituution ja kirjallisen elämän tasoa tutkitaan laajan vastaanottoaineiston avulla, johon kuuluvat omalla tavallaan myös Nissilän omat artikkelit. Tekijä ottaa kantaa kirjalliseen kanonisoitumiseen liittyviin kysymyksiin. Samalla hän itsekin osallistuu kanonisoitumisprosesseihin kirjoittamalla Suomen nykykirjallisuuden historiaan. Hän on joutunut siten, David Perkinsin sanoin, valitsemaan, (re)presentoimaan ja yleistämään. Väitöskirjassa liikutaan siis eri tasoilla ja metatasoilla.

Viimeisessä tutkimusartikkelissa sekä artikkeleita kehystävissä luvuissa Nissilä omistaa paljon tilaa itsereflektiolle ja tutkimustaipaleensa kommentoinnille. Tuskin löytyy väitöskirjaa, joka sisältäisi enemmän itsereflektiota. Sekin sopii erittäin hyvin aiheeseen, johon liittyy määrittelyvaltaa, erilaisia valtadynamiikkoja koskevia ongelmia sekä monia muita eettisiä kysymyksiä. Niitä Nissilä lähestyy hienonvaraisesti pohtimalla kaikkien tasojen keskusteluissa esiintyvää "me" ja "he" -retoriikka sekä termejä, joilla viitataan tutkimuskohteena oleviin kirjailijoihin. Väitöskirjan uusimmissa teksteissä "maahanmuuttaja" kirjoitetaan lainausmerkeissä. Ilman lainausmerkkejä käytetään adjektiiveja maahanmuuttajataustainen ja ylirajainen, jotka ilmeisesti tuntuvat tällä hetkellä sopivimmilta. Tutkija tietenkin tarvitsee käsitteitä, joilla voi operoida mahdollisimman sujuvasti.

Erittäin tärkeä on huomio, jonka Nissilä suo kirjallisuuskentän valtadynamiikalle, "maahanmuuttajakirjallisuuden" erityyppisille tokenismeille ja eksotismeille sekä - Camilla Haavistoon viitaten - erilaisuuden ja toiseuden kontrolloinnille, kesyttämiselle ja lokeroinnille. Hyvin tärkeässä roolissa on ollut kysymys vierauden ja vieraannuttamisen sopivasta asteesta. Kirjallinen instituutio julistaa kaipaavansa vierasta ainesta, mutta se ei saa olla liian vierasta ja outoa. Sellainen on häiritsevämpää kuin Alexandra Salmelan kansallissoitinta fujaraa soittava, haistatteleva ja kiroileva antisankari Pal'o Oškvárok.

Nissilän väitöskirjan tärkeä anti on laaja metodologinen keskustelu. Välillä tuntuu siltä, että varsinkin "ylirajaisuus" ja "metodologinen nationa- 
lismi” -käsitteitä koskevaa pohdintaa on jopa liikaa, kun sitä käsitellään sekä artikkeleissa että niitä kehystävissä luvuissa. On kuitenkin ymmärrettävää, että väitöskirjan ensimmäisessä kahdessa luvussa on pitänyt tarjota tuore ja kokoava katsaus koko ajan kehittyvään avainkäsitteitä koskevaan problematiikkaan ja nostaa esiin suomalaisen kirjallisuuden ylirajaisuus "ennen ja nyt". Kirjallisuuden olemus on ja on aina ollut ylirajaista, ja kirjallisuus, joka ei ylitä tai riko mitään rajoja on tunnetusti melko surkea ilmiö. On kuitenkin selvää, että "vanhat" ylirajaisuudet olivat erilaisia kuin "uudet", nykymaailmassa kehittyneet. Nissilä tarjoaa vanhojen ja uusien ylirajaisuuksien vertailua, mitä on tähän mennessä tehty valitettavan vähän. Taitavasti kontekstualisoiden hän tuo esiin Suomen vanhojen ja uusien vähemmistöjen sekä muun muassa torniolaaksolaisten, meänkielisten, kveenien, ulkosuomalaisten, karjalaisten evakkopakolaisten ja inkeriläisten paluumuuttajien kirjallisuudet. Niiden yhteydessä ylirajaisuus-termi tuntuu oikeutetulta ja kelvolta, varsinkin kun sitä tukee intersektionaalinen lähestymistapa. Näin havainnollistuvat kansalliset, etniset, kielelliset ja muut identiteetit ja niiden välisten rajojen konvergenssit, risteymät ja divergenssit. Nissilä ei kuitenkaan karta ylirajaisuus-käsitteen kritiikkiä: Hän pohtii sen universaaliuden hyötyjä ja haittoja verrattuna esimerkiksi transnationalismi-käsitteeseen.

Metodologinen nationalismi esiintyy usein teoreettismetodologisen keskustelun pahiksena. Tämä kritiikki tuntuu kuitenkin hyvin oikeutetulta, kun tietää, miten vaikeaa on määritellä sellaiset käsitteet kuten "Suomen kirjallisuus" tai "suomalainen kirjallisuus", joihin edelleenkin perustuvat kirjallisen instituution, kirjallisen elämän sekä monen ihmisen ajattelun rakenteet ja lähtökohdat. Noin kahden sadan vuoden aikana vakiintunut kansallisten kirjallisuuksien olemusten luonnollistaminen tai normalisoiminen on edelleenkin hyvin sitkeää.

Hanna-Leena Nissilän väitöskirja on tärkeä saavutus, joka tarjoaa runsaasti uutta tietoa, teoreettismetodologisia avauksia, tarkkoja ja inspiroivia luentoja, tutkijan itsereflektion malleja ja se motivoi kysymään uusia tutkimuskysymyksiä. Lisäksi se on - kaiken hyvän tutkimuksen tapaan - rohkea kannanotto "meitä" ja "heitä" koskeviin ajankohtaisiin ongelmiin.

Viola Parente-Čapková 